\title{
Review
}

\section{経口固形製剤の製造工程における粉体物性の管理と PAT}

\author{
Control of Critical Quality and Performance Attributes of Powder in \\ Manufacturing Processes of Oral Dosage Forms and PAT Application
}

\author{
谷野 忠嗣 \\ Tadatsugu Tanino
}

\begin{abstract}
According to FDA guidance, PAT (Process Analytical Technology) is a system for designing, analyzing, and controlling manufacturing through timely measurements (i.e., during processing) of critical quality and preformance attributes of raw and in-process materials and processes. A desired goal of the PAT framework is to design and develop well understood processes that will consistently ensure a predefined quality at the end of the manufacturing process. PAT tools can be categorized according to the following : 1) Multivariate tools for design, data acquisition and analysis, 2) Process analyzers, 3) Process control tools, 4) Continuous improvement and knowledge management tools.

In this article, process analyzers are introduced and discussed with their actual application under the recognition of PAT as a system.
\end{abstract}

Keywords : Process analytical technology, Process analyzer, Timely measurement, FDA, Near infrared analyzer, Validation

\section{1.はじめに}

FDA (Food and Drug Administration, 米国食 品医薬品局) は2004年 9 月にPAT (Process Analytical Technology) に関するガイダンスを出したが, ドラフト段階での PAT の定義とガイダンスでの正式 な定義とではかなりの差が生じている。ドラフト以前 の段階では，PATは「製造プロセスの連続的な分析 および管理のためのリアルタイムな計測を基盤とした システム, もしくは, 生産完了時において最終製品の 品質適合性を保証するために原料や中間製品の品質お よび操作手順の稼働性能を工程中において迅速に計測

第 42 回粉体に関する討論会（2004 年 9 月、岐皁）にて発表

2005 年 5 月 27 日受付

塩野義製薬 (株) 摂津工場

( 566-0022 大阪府掑津市三島2丁目5番1号) TEL 06-6381-7344

Shionogi \& Co., Ltd., Settsu Plant

(5-1, Mishima 2-chome, Settsu, Osaka 565-0022, Japan)

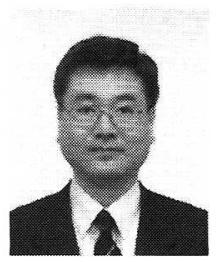

<著者紹介>

昭和 54 年京都大学工学部工業化学科卒業, 同 年塩野義製薬株式会社入社, 平成 8 年薬学博 士。生産技術研究所で経口固形製剤とくに睡 眠導入剂, 抗生物質, 血圧降下剂などの製剂 設計，製造設計を担当。平成 16 年から塩野義 製薬株式会社撕津工場長。
するシステム」と定義（案）されている1）すなわち， PAT はリアルタイムもしくは迅速な計測手段を伴っ た工程分析技術ということになる。一方，ガイダンス での PAT の定義 2 は「リアルタイムな計測により, 工程の設計, 分析, 管理を行い, 最終的に製品の品質 を保証するシステム」としており，工程の設計を前面 に出してプロセスにおける品質の造りこみを重視して いる。また, Analyzingは単なる工程分析ではな く, 統合された方法で化学的, 物理的, 微生物学的, 数学的, リスクベース的に分析を行うことと広範囲な 解釈を示している。そして, PAT の枠組みの望まし いゴールは製造工程の最終段階で予め設定した品質を 必ず保証できる, 十分に理解の行き届いた工程を設計

し開発することであるとしている。

PATはシステムであり, 四つの構成要素から成り 立っている。すなわち, Table 1 に示すように, 統計 解析的なッール, 工程分析ツール, 工程管理ツール, 継続的改善ツールである。これらのッールがシステマ ティックにコンビネートされたシステムがPAT であ る。ドラフトでは，これらのツールの定義がより具体 的であったが, ガイダンスとなってからはやや抽象化 された定義となっており，PATをより包括的なも の，概念的なものとしょうとするFDAの姿勢が伺え 
Table 1 PAT tools

(1) Multivariate tools for design, data acquisition and analysis

(2) Process analyzers

(3) Process control tools

(4) Continuous improvement and knowledge management tools

る。今まで，国内ではこれらの要素のうち，工程分析 ツールに焦点をあててPAT を議論する傾向が見ら れ，このことに対する批判も少なからずあったが，一 方では，工程分析ツール無くして，残りの三つのッ一 ルが機能しないことは自明であり，PAT の根幹をな す最も重要なツールであることに疑う余地はない。し たがって，本稿では，PATをシステムとして把握し たうえで，工程分析ツールの具体例について議論して ゆきたいと考える。

\section{2. 工程分析ツール}

\section{1 NIR}

工程分析ッールで最も注目されているのはNIR (Near Infrared Analyzer, 近赤外分光分析）であ る。これに関しては，FDA や外資系企業からすでに 多くの実例紹介がある。NIR の特徴は Table 2 に示し たとおり，非破壊試験であること，非接触で測定可能 なこと，非污染源であることなど，リアルタイムな工 程分析ツールが具備すべき要件を満たしている。応用 例としては, 混合工程における混合均一性のリアル夕 イム測定，打錠工程における含量のリアルタイム測 定などであるが，新たな NIR の応用例として CDER (Center for Drug Evaluation \& Research)の物理 薬剂学チームにより, 水和物の分離定量, 錠剂の溶出 性の予測などが紹介されている。これらについてごく 簡単に紹介する。

二つの成形物（コア） A およびBが充填されている

Table 2 Merits of NIR
1. Real time analysis
2. Non destructive
3. Analysis of plural excipients at the same time
4. Non contamination
5. Non contact
6. Evaluation of blend uniformity without sampling error

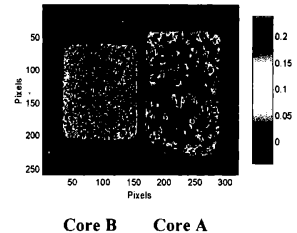

Core A : Conc. of anhydrous NIR estimation $=8 \%$ actual $=9 \%$

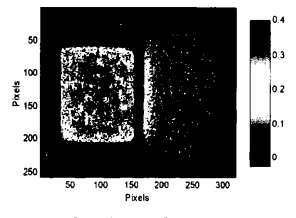

Core B Core A

Core B : Conc. of monohydrate NIR estimation $=50 \%$ actual $=40 \%$
Fig. 1 Real time analysis of nitrofurantoin anhydrous and mono-hydrate in capsule by NIR

Nitrofurantoin の市販カプセル剂を，NIRで分析す ると，コアAには無水物が推定 $8 \%$ (実際 $9 \%$ ), コ アBには一水和物が推定 $50 \%$ （実際 $40 \%$ ）含有され ていることがリアルタイムに測定可能であるとした事 例報告が Fig. 1 である ${ }^{3)}$ 。

次に Fig. 2 は，錠剂から主薬の溶出性の予測に関す るもので, Furosemide を主薬とする直接粉末圧縮法 （直打法）による錠剤の NIR による溶出性の予測と実 際の溶出試験結果との相関が紹介されている。直打法 の場合, 溶出速度に影響をおよぼす変動要因は, 主薬 の粒子径, 主薬の分散状態, 滑沢剂の混合レベル（混 合機および打錠機内），打錠圧力などであるが，これ らのどの変動要因を NIR で評価したのか，あるいは 複合して評価したのかは示されていないが，非常に興 味深い事例である ${ }^{3)}$ 。

ただし，錠剤となってしまってから含量や溶出が評 価されても当該ロットにフィードバックする術はない ので，望ましくは工程が調整可能な段階でこれらの情 報が得られるのが望ましい。そういった意味では，打 錠開始時の試打錠の段階でリアルタイムな計測により 溶出性を推定して，打錠圧力を調整したのち工程を開 始し，その後，工程が適正に維持されていることを

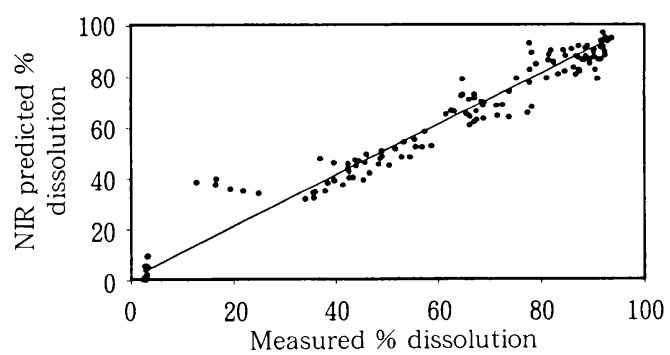

Fig. 2 Prediction of dissolution behavior by NIR sample : Directly compressed tablet of furosemide (\% dissolved at $15 \mathrm{~min}$ ) 
1. Conventional approach-lab based

End of phase testing of quality ; to reduce the risk in moving to the next stage

\begin{tabular}{|c|c|c|c|}
\hline $\begin{array}{c}\text { Contain raw } \\
\text { materials }\end{array}$ & $\begin{array}{c}\text { Mix active and } \\
\text { excipients }\end{array}$ & Press tablets & Package \\
\hline
\end{tabular}

2. PAT approach-process based, at-line or on-line

$\begin{gathered}\text { Contain raw } \\ \text { materials }\end{gathered}$
Mix active and
excipients $\rightarrow$ Press tablets $\rightarrow$ Package

Continuously or more frequently tast quality during each phase, to remove the risk in moving to the next stage

reference) Norman Winskill, Steve Hammond, "An Industry Perspective on the Potential for

Emerging Process Analytical Technologies",
http://www.fda gov/ohrms/dockets/ac/02/oriefing/3841 B1_05_PFIZED/sld003.htm

Fig. 3 Process control philosophy-paradigm shift with application of PAT

NIRでリアルタイムにモニタリングするなどの方法 が有効である。

湿式顆粒圧縮法（湿式法）であれば，造粒工程のど のパラメータが溶出性に影響をおよぼすのかを充分に 把握したうえで, これらのパラメータをリアルタイム にモニタリングや制御することが頑健な工程を設計す る上で重要である。

PATには先述の四つのッールがシステマティック にコンビネートされていることが必要であり，これら を機能的に運用することによって, 得られた工程デー 夕をどのように活用するかといったアルゴリズムが今 後重要となってくるが, これらに関しての議論はまだ 充分しつくされていないように見受けられる。すなわ ち，単なる工程監視のための PAT をプロセスアナラ イザー（工程分析ツール）の導入，四つのツールがコ ンビネートされたシステムをFDA が定義するPAT とすれば，欧米においてもまだ，プロセスアナライ ザーに視点がおかれているのが実情のように見受けら れる。

確かにNIRなどを導入すれば，そのリアルタイム な測定機能により，HPLCを使用する場合よりも，

Fig. 3 に示すように非常に多くのポイントで含量の測 定ができるようになる4)。しかも，ルーチンに組み込 むことによりバリデーションロット以外の通常ロット にも適用可能となるので, 生産ロットの品質保証の レベルは飛躍的に向上することになる。しかし，これ はあくまでも品質保証のレベルの向上であって, 生産 ロットそのものの品質の向上や工程能力の改善に結び つくものではない。このことはファイザーの Steve Hammond 氏が指摘しているとおりである5)。PAT を品質向上や工程能力向上の目的で活用するならば, システムとしての PAT の活用を指向しなければなら
ないのは自明である。

PAT の実施例として盛んに欧米で報告されるのが, NIRによる混合均一性のリアルタイム計測と打錠工 程における錠剤の含量および含量均一性のリアルタイ ム計測であることは先述した。再三にわたって述べて いるように，工程分析ツールで得られる情報は工程に フィードバックし，工程のより正確な管理と工程能力 の向上のために活用するといった観点から考えた場 合, 錠剂品質すなわち含量均一性, 溶出性, 硬度など は，すでに打錠工程以前の段階で大部分が造り込まれ てしまっているのであって, 打錠工程で得られるリア ルタイムなデータのフィードバック先は当該ロットに 対しては打錠圧力や重量調節以外はほとんど無くなっ ている。つまり，打錠工程における工程分析ッール は，当該ロットの品質向上ではなく，品質保証のレベ ル向上と次回バッチへの品質向上が主目的となる。こ の意味では，造粒工程における工程分析ツール，すな わち, リアルタイムに当該ロットへフィードバックし 品質を造り込むものとは性格がかなり異なっている と言える。逆の見方をすれば，錠剤品質のかなりの部 分を造り込んでいる造粒工程を対象とした工程分析 ッールが，もっと注目されて良いのではないかと考え る。

これらの工程分析ツールは汎用的なツールとして普 及しているものもあれば, 製品の特性やケーススタデ イにより新規に開発されたもの，あるいは今後開発が 必要なものがある。今回はこれらのうちすでに実用に 供されているものについて紹介してみたい。

\section{2 物理的品質のリアルタイムな計測技術の例}

\section{2.1 打錠工程のリアルタイム計測技術}

打錠設備はいち早くリアルタイムな計測技術が導入 され，打錠品質の高度な保証が指向されたものであ る。Fig. 4 はごく一般的な打錠設備の模式図である が, 上下杵間距離を固定した場合, 打錠圧力と錠剂重 量に直線関係があることを利用して，PCD (Pressure Control Device，圧力制御装置）により打錠個々の 打錠圧力をリアルタイムに測定し，この值により錠剂 重量の自動調整を行うとともに, 錠剤個々の重量を監 視して重量過不足錠は系外に排除される。このシステ ムにより錠剂全数の重量の保証が可能となっている が，打錠圧力は温度や打錠用顆粒の粒度などによりド リフトするため, 一定時間ごとに錠剂の実重量を自動 測定するWAC (Weight Automatic Control) 装置 により PCD 装置に補正をかけることが通常である。 なお, 最近では錠剤の厚み, 径, 硬度なども同時に自 


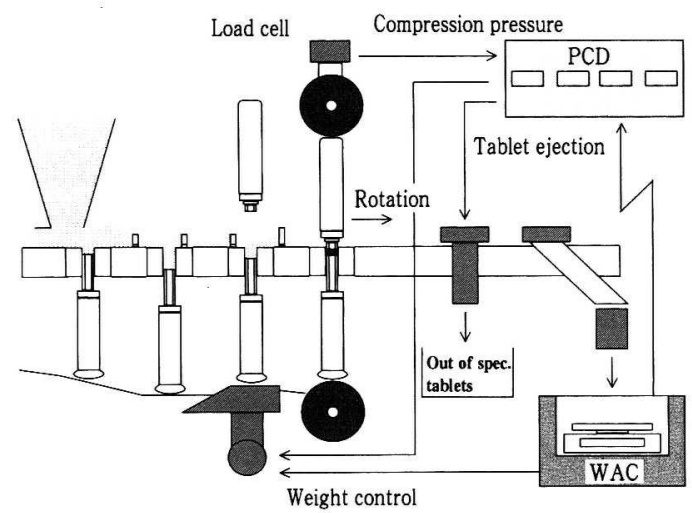

Fig. 4 Automated tablet compression system

動測定する TM5 (Tablet Measuring Device 5) な どの装置も市販されるようになり，錠剤の物理的品質 保証のレベル向上に著しく寄与している。

\section{2.2 錠剂外観のリアルタイムな計測技術}

錠剂外観検査機も工程分析ツールの一例として挙げ ることができる。かつては，錠剤の外観は打錠中に作 業者による定期的な抜き取り検査もしくは全数目視検 查で保証されてきたが, 不良検出力の個人差や作業者 の体調などで，一定の保証水準を維持するのは困難な 場合があった。現在では Fig. 5 に示すような自動外観
検查機が市販されており，打錠機と直結して使用した 場合には，錠剤の外観をリアルタイムに検査すること ができ, 打錠工程で何らかのトラブルなどが発生して 錠剂外観とくに異物混入率に異常が生じた場合は, 打 錠機を直ちに停止させるなどの処置がとれるようにな っている。

\section{2.3 スティッキング自動検査システム}

スティッキングは錠剂外観品質に大きく影響を及ぼ す打錠障害ではあるが，打錠後に錠剂が二つに割れる キャッピングほど致命的なトラブルとは捉えられない ことも多い。しかしながら，社章や製品コードなどの 刻印が判読できなくなるようなスティッキングはもち ろん致命欠陥であるし，軽度のスティッキングは錠剤 外観検査機での検査が困難であることを考虑すれば, 打錠機の無人運転が盛んに実施されている咋今におい て，その及ぼす影響はかつての有人打錠が主流であっ た時代よりもより大きなものとなりつつある。ここで 紹介するのは Fig. 6 に示すように上杵面, 下杵面をそ れぞれ CCD カメラで撮像して，スティッキングの発 生状況をリアルタイムに計測する装置であり,このシ ステムを導入することにより夜間無人運転を実施する 場合, スティッキングによる問題がかなり軽減されて いる ${ }^{6)}$ 。
Control panel

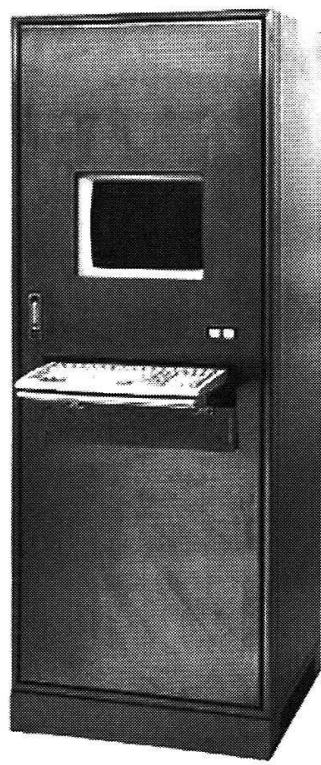

Appearance inspection machine

(1)

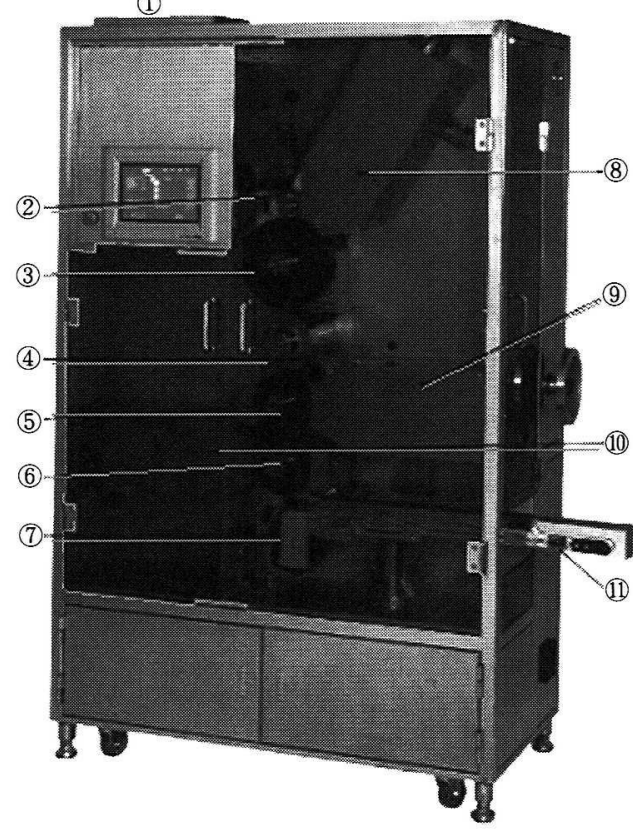

(1) Hopper

(2) Feeder

(3) Side surface inspection roller

(4) Posture converter

(5) Surface inspection roller

(6) Back surface inspection roller

(7) Selector of acceptable tablets

(8) Camera for side surface inspection

(9) Camera for surface inspection

(10) Camera for back surface inspection

(11) Exit belt for acceptable tablets

Fig. 5 Tablet appearance inspection machine 


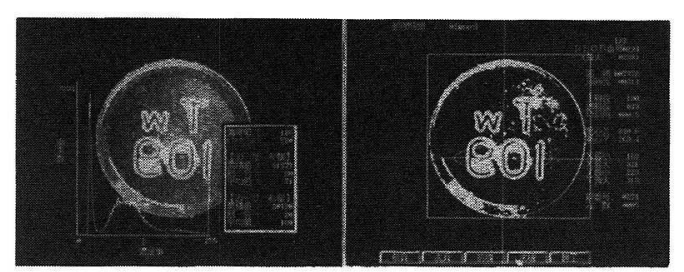

Fig. 6 Real time sticking monitoring device Gray image (left), Digital image (right)

以上，実用化されている打錠工程での工程分析ッー ルの例のごく一部を紹介したが，これらはいずれも本 来は無人化を指向して開発された設備であることにお 気づきいただけると思う。すなわち, 工程分析ッール は作業者に代わって工程を監視・制御するという側面 を有すると考えることができる。

\section{3. 造粒工程における工程分析ッールの重要性}

今までは，打錠工程などの最終工程またはその直前 の混合工程での工程分析ッールについて述べてきた が，冒頭でも若干触れたように錠剤品質は打錠工程以 前の工程で大部分が造り込まれており，極論すれば打 錠工程は先行する工程で造り込まれた品質を単に具現 化しているだけとも言える。つまり，打錠工程でリア ルタイムに含量均一性を評洒した場合, ロットの細部 にわたる品質評価が実施でき, 当該ロットの品質保証 のレベルは格段に向上するが, 先行工程に不具合があ った場合, いくら打錠工程で工程分析ツールを適用し
て出来上がった製品品質を評価しても，ロットそのも のの品質を改善することは期待できない。そもそも， 打錠工程で含量均一性に問題が生じる原因がどこにあ るのかという根本原因の追求なくして, 打錠工程に工 程分析ツールを導入することは本質的でないと言わざ るを得ない。

例えば， Fig. 7 に含量均一性に問題が生ずるときの 原因の例，すなわち，打錠用顆粒の粒度別含量が不適 切な分布となっている例を示したが， 60 号篩不通の 部分の主薬含量が $700 \%$ 近い極端なものとなってお り, 打錠中の粒度偏析が直ちに錠剂の含量バラッキの 原因となっていることが分かる7゙。この対策を打錠工 程に期待することは困難であり, 造粒〜整粒工程で 60 号不通の粒度部分を無くすことが根本的な解決手 段となる。Fig. 7 の例では 60 号篩不通部分がなくな るような整粒条件を採用した結果，含量均一性が全く 問題ないレベルに改善できている。つまり, 妥当な造 粒条件と製粒条件を設定し, 粒度分布を適性に維持管 理しておけば，打錠工程での含量均一性に問題が生じ ることはほとんどなくなる。これらのことは, 工業化 研究の段階で工程設計として実施されているべきこと であり,このことがあって初めて打錠工程におけるバ リデーションが意味を持ってくるし, 品質保証として のPAT も意味を有してくる。さらに突き詰めれば, 打錠工程における含量測定のためのリアルタイムな NIR 分析が依然として抜き取り検査であることを考 えると，ロット全体の品質保証という観点からすれ

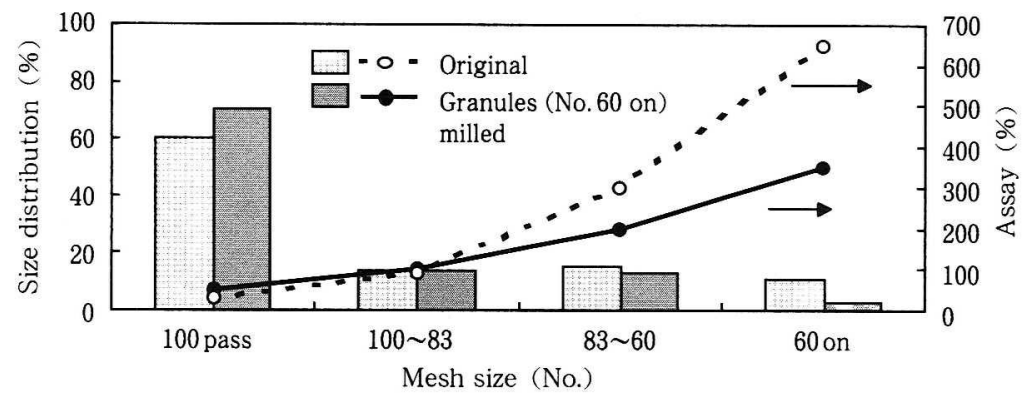

Content uniformity of tablets $(n=10)$

\begin{tabular}{lrrc}
\hline & & Original & Granules (No.60 on) milled \\
\hline Average $(\%)$ & 98.0 & 97.8 \\
$\max$ & $(\%)$ & 109.1 & 102.3 \\
$\min$ & $(\%)$ & 85.1 & 94.6 \\
C.V. & $(\%)$ & 6.36 & 1.95 \\
\hline
\end{tabular}

Fig. 7 Mesh cuts assay of lubricated granules and content uniformity of tablets 


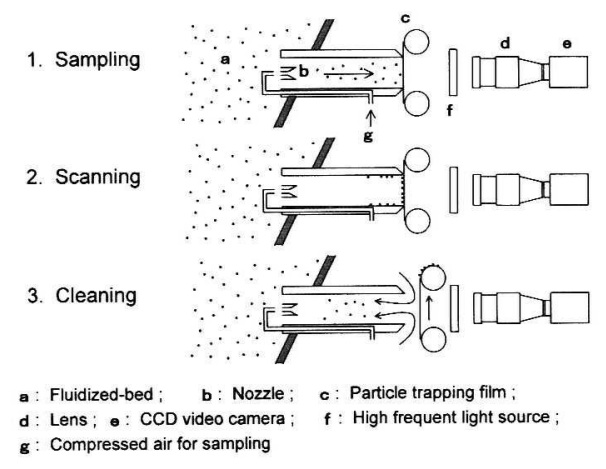

Fig. 8 Real time monitoring system of granule size distribution in fluidized-bed granulator

ば，造粒〜製粒工程における粒度別含量測定などへの 工程分析ッールの適用がより重要な意義を有すると考 えられる。

ちなみに, 含量均一性や溶出性, 硬度, 崩壊, 摩損 度などの錠剤品質に対する変動要因としてまず重要な のは，主薬の粒子径などの原料物性である。これにつ いては，製剂設計の段階から充分な検討がなされ，細 かな規格が設定されている場合がほとんどであり，規 格に合致しない粒度の原薬に対しては粉砕処理などの 対応がなされる。欧米で普通に実施されている直接打 錠の場合, この原料の粒度管理は極めて重要である。 そして, 次に重要となるのが造粒工程である。造粒工 程では造粒不足や造粒過剩によって錠剤品質が大きく 変化するし，粒剤の場合は錠剂の場合よりもっと直接 的に品質が決定つけられてしまう。したがって, 製品 品質を規格内に保つためには造粒度を規格内に維持す ることが必要である。つまり, 造粒工程において, 造 粒の進行度すなわち造粒度を適正に維持・管理するた めの工程分析ツールの適用が非常に重要であり，これ らはまさに品質を造り込むためのッールといえる。そ の具体例を以下に若干紹介してみたい。

\section{1 流動層造粒における画像解析法による粒度管 理 ${ }^{8)}$}

胃潰瘍などに処方される乾燥水酸化アルミニウムゲ ルと酸化マグネシウムを成分とする制酸剤を流動層で 造粒する場合, 非晶質である水酸化アルミニウムゲル の劣化に注意が必要である。水酸化アルミニウムは非 晶質であることが制酸効果を発現するための絶対条件 であるが, 流動層造粒時の温度と湿度の条件は非晶質 を結晶化させるための加速条件でもある。このため, できるだけ短時間で造粒を完了させて乾燥を行うこと

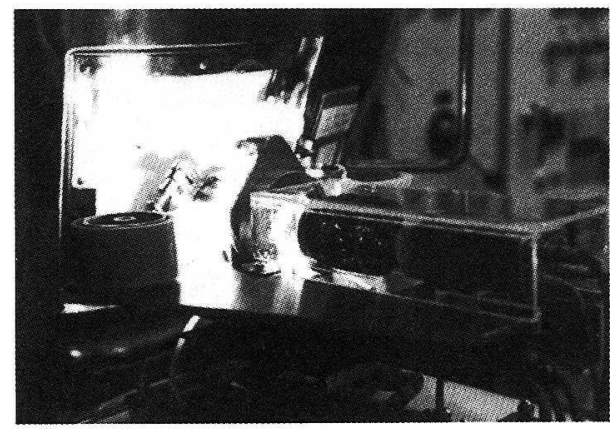

Fig. 9 Appearance of real time monitoring system of granule size distribution in fluidized-bed granulator

が必要である, しかしながら, 水酸化アルミニウムゲ ルは多量に水を保持するため, 造粒をすばやく進めよ うと思えばスプレー液速度をかなり速くしなければな らない。このような造粒条件を採用した場合，造粒は ある点を境に一気に進行するパターンとなり，わずか 1 ～分の間で造粒時間を制御しなければ, 造粒過剩 あるいは造粒不足の事態となる。ちなみに, 造粒過㮃 ロットは崩壊の遅延, 造粒不足ロットは顆粒収率の低 下などの問題が生じる。

そこで，造粒中の粒度をリアルタイムで計測し，流 動層の制御装置にフィードバックするシステムが開発 されている。Fig. 8 は, 流動層内部から粒子をサンプ リングする装置である。流動層コンテナの側壁にサン プリング筒を貫通させ, コンテナ内部に压空ノズルを 筒の外方向に向かって設置し, 筒の出口には透明粘着 テープを密着させたごく簡単な構造である。流動層内 で造粒中の粒子は, ノズルから噴出させた压縮空気に より少量がサンプリング筒内を通過して透明粘着テー プ表面に吹き飛ばされ固定される。固定された粒子は CCD カメラにより撮影され, その後, 透明粘着テー プは巻取られて新しい面がセットされる。CCD カメ ラからのアナログ像はデジタル変換されて, 粒子径は これと同一面積の円の直径として近似される。撮像し た全粒子についてこの演算処理を行えば, サンプリン グした造粒物の粒度分布や平均粒子径を簡単に求める ことができる。これらの処理や演算はコンピュータに より実施されるが, このコンピュータに予め粒度の規 格值や造粒終点の粒度を入力しておけば，所定の粒度 となった時点で造粒を終了することができる。Fig. 9 はこのシステムの実物写真を示したものであるが, こ の方法の最大の特徴は, 造粒物の粒度を直接リアルタ イムに測定する方式であるため, 品温や水分などの間 
Table 3 Dissolution behavior of tablets produced monitoring integrated power consumption $W_{\mathrm{T}}$

\begin{tabular}{|c|c|c|c|c|}
\hline & & Batch No. 1 & Batch No. 2 & Batch No. 3 \\
\hline \multicolumn{5}{|l|}{ Granulation time } \\
\hline & $(\min )$ & 22.2 & 15.2 & 14.7 \\
\hline \multicolumn{5}{|l|}{ Dried granule size } \\
\hline & $(355 \mu \mathrm{m})$ on & 31.0 & 33.1 & 33.9 \\
\hline & $(75 \mu \mathrm{m})$ pass & 6.9 & 5.8 & 6.0 \\
\hline \multicolumn{5}{|l|}{ Sized granule size } \\
\hline & $(355 \mu \mathrm{m})$ on & 14.1 & 15.9 & 15.7 \\
\hline & $(75 \mu \mathrm{m})$ pass & 9.8 & 11.1 & 11.3 \\
\hline Loose bulk density & $(\mathrm{g} / \mathrm{m} l)$ & 0.54 & 0.56 & 0.56 \\
\hline \multicolumn{5}{|l|}{ Tablet property } \\
\hline Thickness & $(\mathrm{mm}) \mathrm{n}=10$ & 2.35 & 2.34 & 2.35 \\
\hline Hardness & $(\mathrm{kg}) \mathrm{n}=3$ & 7.1 & 6.4 & 6.1 \\
\hline Disintegration & $(\min ) \mathrm{n}=3$ & 3.2 & 4.1 & 3.2 \\
\hline \multicolumn{5}{|l|}{ Dissolution } \\
\hline $\mathrm{pH} 5.5 ; D_{75}$ & (\%) $\mathrm{n}=3$ & 44.4 & 42.0 & 44.2 \\
\hline
\end{tabular}

Spce.

$46.3 \pm 5 \%$

接因子を制御する方式よりもより直接的で高い信頼性 が得られることにある。この工程分析ツールにより, わずか数分間で著しく変化する造粒度を適正に維持す ることが可能となっており, 現在もその性能を発揮し 続けている。

\section{2 摫挟造粒における消費電力積算による造粒度 の管理 ${ }^{9}$}

攪拌造粒法は国内外を問わず汎用されている造粒方 法であり，製剂機械メーカーごとに種々のタイプの攪 找造粒機か販売されている。この造粒法は流動層造粒 法と比較して変動要因は少ないが，それでもスケール アップに関しての一般解はまだ得られておらず，しか も, ベッセルやアジテータの形状がメーカーによって さまざまであるため, 同一スケールであっても, 機種 間で同じ造粒物を得ることはかなり困難である。とく に，缷拌回転数をいくらに設定するかは非常に重要で あり, 攪找翼先端の周速度を揃えるとか加速度を揃え るとかの方法が提案されているが，これらには造粒時 間という変動要因が考慮されておらず，何分造粒す るかについては感覚的・経験的な対応が必要となる場 合があった。この問題点に対して筧拌距離を揃えると いう考え方が提案され ${ }^{(0)}$, 初めて造粒時間を変動要因 として考慮した提案がなされ注目されているが, 装 置が大型化するにつれて造粒時間を短くしなければな らないことに対して補正が必要であるとする意見もあ る。

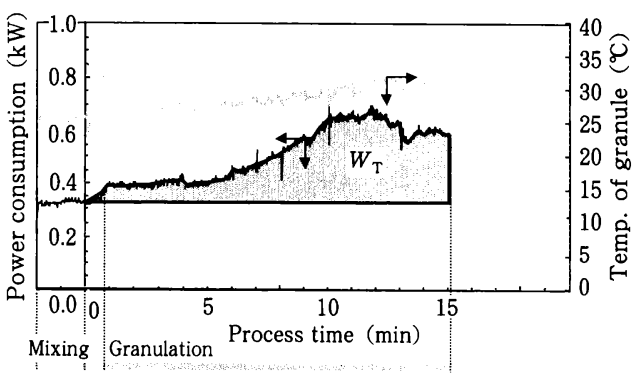

Fig. 10 Detection of end point in agitating granulation by monitoring integrated power consumption $W_{\mathrm{T}}$

ここで紹介する造粒状態のモニタリング法は，Fig. 10 に示すように, 撜拌造粒に使用した消費電力の積 算值すなわち攪拌造粒に使用された全エネルギーを計 測するものであり, 従来の時々刻々の消費電力をモ二 タリングする造粒終点制御法のように, インバータの スポット的なノイズによる誤検知がなく，また，消費 電力の変化が小さい場合にも適用可能である。

この方法を適用した例を紹介する。Fig. 11 はある錠 剂からの主薬の溶出特性と造粒時間との関係を示した ものであるが, わずか 1 分の造粒時間の差で溶出規格 に適合するか不適合となるかの非常にクリティカルな 製品であり，通常の造粒工程でこの製品を製造しょう とすれば明らかに工程能力が不足し，バリデーション 


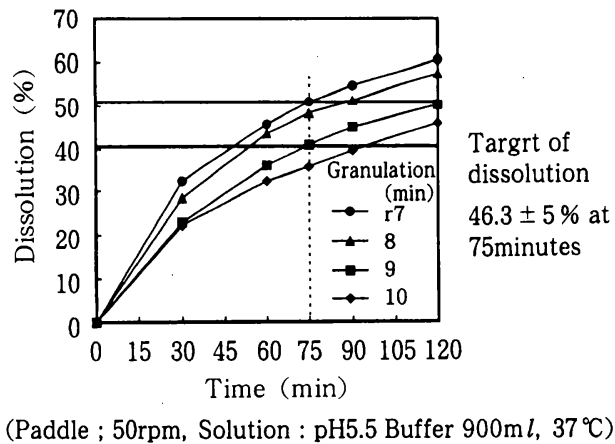

Fig. 11 Relationship between granulation time and dissolution behavior of tablet $\mathrm{A}$

が不成立となることが考えられる。ところが本手法の 場合, Table 3 に示すように, 予め最適化検討で設定 しておいた積算消費電力 $2500 \mathrm{~kJ}$ で造粒を終了する と, 1 バッチめの造粒時間は 22 分であったが, 2 バ ッチめ 3 バッチめのそれはおよそ 15 分と造粒時間が 大きく短縮した。しかし, 得られた錠剤の溶出挙動は 規格に適合するものであった。

\section{3 遠心転動流動層における被覆造粒状態の管} 理 ${ }^{11}$

Fig. 12 に示す遠心転動流動層 (CF) を用いた被覆造 粒は，徐放性製剂などを製造するのに極めて有用な方 法であり, 球形芯顆粒に結合剂の液をスプレーして適 度に湿潤させた後, 有効成分を含有する粉末を適量散 布するという操作を繰り返すことで被覆造粒を実施す るものである。このとき，スプレーする液の量が過剩 であると粒子同士が凝集して粗大粒が発生し, 逆に不 足すると散布した粉末が完全に被覆されずに散布粉末 のみで凝集物を形成したり吸引により系外へ飛散する などの問題が生じる。いずれの場合にも, 製品品質と りわけ溶出速度に大きな変動が発生する。この結合液 による顆粒表面の適正な湿潤度の範囲は極めて狭く, 水分計などでモニタリングできないこともしばしばで ある。このような作業は習熟した専任の作業者により 実施されることが多いが, それでも工程能力は非常に

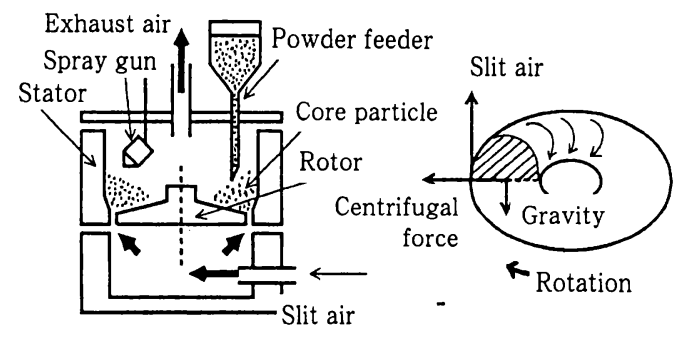

Fig. 12 CF granulation system

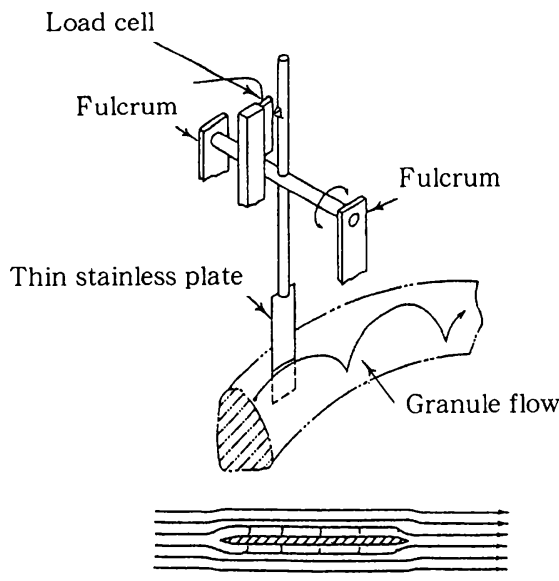

Fig. 13 Real time monitoring sensor of granule wetness in $\mathrm{CF}$ granulator

低く, 得られる顆粒の溶出のバラツキは非常に大きな ものであった。そこで適正な顆粒表面の湿潤度を検出 するために Fig. 13 に示すようなセンサーを開発した。 このセンサーは, 転動している顆粒の中に棒を突っ込 んだだけの簡単なものであるが，顆粒の表面が需れる と顆粒間が液体架橋するためセンサーに生じる抵抗力 が増大し出力が大きくなる。逆に, 顆粒表面の湿潤度 が低下すると粒子間の付着力が減少してサラサラの状 態となり，センサーに生じる抵抗力が小さくなって出 力が低下する。このため被覆造粒中は顆粒の湿潤度に 対応する信号をリアルタイムに計測し，スプレーの $\mathrm{ON}$ OFFにフィードバックし一定範囲内で維持すれ ば，顆粒の湿潤状態を適正に維持することが可能とな る。このセンサーを使用した場合, 得られる顆粒の溶 出速度を Fig. 14 のように精度よく制御することが可 能となった。この例も, やはり工程が不安定でバリ デートが困難なプロセスを，工程分析ツールと工程制 御ツールによりバリデート可能とした好例である。

これら以外にも，赤外線水分計と熱収支・物質収支 の理論計算を組み合わせた流動層造粒のスケールアッ プ12.13) や，光透過センサーによる転動流動層の造粒 状態のリアルタイム計測技術 ${ }^{14)}$ ，音響センサーによる

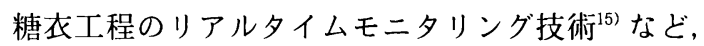
日本には工程分析機ツールとしての実用例が数多く報 告されているので是非ご参照いただきたい。

\section{4.おわりに}

本稿ではFDA のガイダンスにしたがってPATを 論じた。現在，日本国内で完全に定着しているバリ デーションは必ずしも工程改善や品質向上を目指すも 

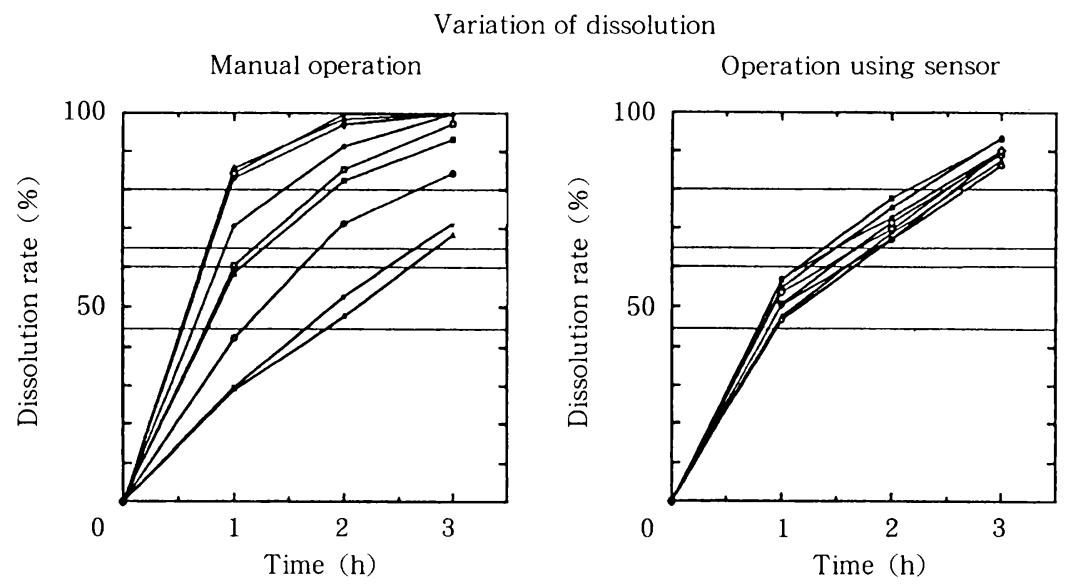

Fig. 14 Uniformed dissolution behavior by using real time monitoring sensor of granule wetness

のではなく，工程の適格性を検証するものである。つ まり, バリデーションは工業化研究や最適化研究によ り変動要因に対してワーストケースにおけるチャレン ジテストが実施され，充分に最適化された工程に対し てその適格性を検証する行為である。しかしながら， 粉体プロセスを伴う固形製剂の製造プロセスでは, 原 料の物性をはじめとして, 各工程における変動要因は 時々刻々と変動しているのが実情であり, バリデーシ ョンの前提たる工業化研究や最適化研究が, これら を完全に包括しているか否かに疑問を投じた結果が FDA の PAT の導入に結びついているとも解釈でき る。ちなみに, FDA の PAT チームと製造科学ワー キンググループが共同で作成した白書「Innovation and Continuous Improvement in Pharmaceutical Manufacturing Pharmaceutical CGMPs for the

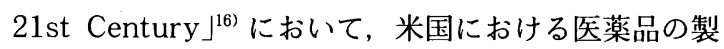
造プロセスを「進歩のない静的な製造作業」と表現し ている。すなわち, 問題点や改善点があるにもかかわ らず，一旦バリデートされた製造プロセスであるがた めに, 現状を静的に継続する実情, そして OOS (Out of Specification) が発生しても, 製品あるいは工程 の基本設計の見通し, 設定規格の改定などに生かされ にくい実情を非効率的でコスト高な製造形態であると し, 他の産業と比較した場合, 近代的な工程設計の理 念, 新規の測定・管理技術, 知識マネジメントシステ ムの導入にもっと積極的に取り組むべき余地があると している。PAT はこれらの実情に対処すべく導入さ れたものであり, 工程をよりょく理解し, ょり頑健な プロセスを設計し, 継続して品質向上, 工程改善を実 施することを目的とするものである。
従来からわが国内で盛んに実施されてきた工程の自 動化技術とPAT が，ともに変動要因や中間製品品質 のリアルタイムな計測技術と製造条件へのフィードバ ック機能を有し, 両者の機能に共通点があることから 両者を同次元に解釈した時期があった。しかしなが ら, 自動化技術は工程を正常に維持し, バリデーショ ンをサポートし，あるいは無人化を指向するものであ るのに対し，システムとしてのPAT は, 製品のライ フサイクルの全期間を通じて工程をリアルタイムに深 く理解し, 検出された問題点や新たな変動要因を最適 化しながらより頑健な工程を設計し, 継続して品質向 上を目指すものである。両者はその目的とするところ が異なっていることを認識すべきであり，そして，工 程分析ツールを伴った自動化技術は, システムとして のPAT のッールのひとつとして認識すべきである。 本稿で紹介した工程分析ツールも同様にPAT のッー ルの一つとして認識いただきたい。ただし，これらの ッールはPAT の根幹をなすものとして極めて重要で あることは冒頭で述べたとおりである。

他方，欧米における工程分析ツールの実例は NIR にかなり偏重しており，NIR 以外のさまざまな工程 分析ツールが今後新規に開発されてゆこうとする現状 においては，FDAのPATガイダンスは概念が非常 に先行した特異な形態となっている。つまり, PAT の概念を先に浸透させることにより，概念と実際との 乘離をポテンシャルとして新規な技術導入を強力に促 進しようとする FDA の姿勢をみることができる。

米国における医薬品の製造の実情と日本における実 情との間にある程度の差があることは事実としても， ICH (International Conference of Harmonization) 
によるグローバル化が猛烈なスピードで進む状況にお いては, 日本の医薬品が世界市場で通用するために, バリデーションと同様にPAT $\mathrm{PA}$ 避けて通れないもの となる可能性は非常に高い。日本の医薬品が頑健な製 造プロセスのもとで生産されたものであると海外の規
制当局から理解を得るためには, あらためて PAT と いう概念をFDA のガイダンスのもとで再確認し, 日 本における製造の現状とPAT の今後の展開について グローバルな理解を得ることがますます重要になると 思われる。

\section{References}

1) Ajaz S. Hussain : "The Subcommittee on Process Analytical Technologies (PAT) : Overview and Objectives", Gaithersburg, MD, February 25 (2002) http : //www.fda.gov/ ohrms/dockets/ac/02/ slides/ 3841s1_01_hussain.ppt

2 ) Guidance for Industry, PAT-a Framework for Innovative Pharmaceutical Development, Manufacturing, and Quality Assurance (September, 2004)

3 ) Advancing Critical Path Research (October, 2004) http : //www.fda.gov/ohrma/dockets/ac/04/slides/ 2004-4078S1_13_Khan.ppt

4 ) Norman Winskill, Steve Hammond: "An Industry Perspective on the Potential for Emerging Process Analytical Technologies", http ://www.fda.gov/ohrms/dockets/ac/02/briefing/ 3841B1_05_PFIZER/sld003.htm

5 ) ISPE Japan Affiliate : "Report of the First Winter Conference Sponsored by ISPE Japan Affiliate”, PHARM TECH JAPAN, 19, 905-913 (2003)

6 ) Harada, K., H. Suzuki, T. Nakaoka and T. Makino : "Detection of Sticking by using Image Sensor", Journal of Japan Society of Pharmaceutical Machinery and Engineering, 7, 4-12 (1998)

7 ) Tanino, T. : "Control of Granulation to Keep Content Uniformity", Abstract of Papers, Powrex Gijutu Kouenkai, 99-7B (1999)

8 ) Tanino, T. : "Granule Size Control in Fluidized-bed Granulation", Abstracts of papers, Sixth International Symposium on Agglomeration (Nagoya), p. 548 (1993)

9 ) Hayakawa, H. : "Determination of End Point in Agitating Granulation by Monitoring Integrated Power
Consumption", Abstract of papers, The $20^{\text {th }}$ Symposium on Particle Preparations and Designs, pp. 193197 (2003)

10) Ashihara, K.: "Scale up Study of Agitating Granulation", Abstract of papers, Standard Formulation Research Association, p. 8 (1995)

11) Tanino, T. and Y. Tomoda: "Variables Affecting the Dissolution Behavior of Sustained Release Granules", Abstract of papers, International Symposium on Controlled Release of Bio-active Materials (Kyoto), p. 214 (1996)

12) Aoki, Y.: "Scale up Strategy of Fluidized-bed Granulation", Abstract of papers The $12^{\text {th }}$ Symposium on Particle Preparations and Designs, p. 203 (1995)

13) Tanino, T. and T. Mizuta: "Strategy of Scale-up in Fluidized-bed Granulation”, Abstract of papers, PDA International Congress (Tokyo), p. 147 (1999)

14) Morimoto, S. : "Development of Granulation Control Technology Monitoring Light Penetration Degree Across Fluidized-bed", Abstract of papers, Standard Formulation Research Association, p. 55 (1996)

15) Yoshida, T. : "Control of Sugar Coating Process Using Sound Analyzer", Abstract of Papers, The $18^{\text {th }}$ Symposium on Particle Preparations and Designs, p. 139 (2001)

16) The PAT Team and Manufacturing Science Working Group, "Innovation and Continuous Improvement in Pharmaceutical Manufacturing Pharmaceutical CGMPs for the 21st Century",

http ://www.fda.gov/cder/gmp/gmp2004/manufSciWP.pdf 